\title{
Discuss "It Can Be Argued That Management Is Largely Concerned With Leadership, Because Managers Need To Establish A Sense of Direction and To Motive People in That Direction." (Hannagan)
}

\author{
Wen BAI, Yajun ZHAO \\ Department of Economics, Shenyang TV\& Broadcast University \\ Department of Foreign Language, Shenyang TV\& Broadcast University
}

\begin{abstract}
Hanngan (2002) states that "it can be argued that management is largely concerned with leadership, because managers need to establish a sense of direction and to motivate people in that direction." To discuss this statement, it seems valuable to clarify the relationship between management and leadership and what managers do. In addition, leadership and "managers need to establish a sense of direction and to motivate people in that direction" reflect that this statement is concerned with strategic management since it can be a strategy for managers to establish direction and to motivate people.
\end{abstract}

Index Terms -leadership. Management. strategic management.

\section{Introduction}

In the past thirty years, there are increasingly litereatures that argue management, leadership and strategic management. According to these literatures, the purpose of this paper is going to argue whether Hannagan's statement is reasonable. Therefore, firstly, this paper will draw a profile of management and leadership which may include the defnition of management and leadership, the functions of management and leadership, and the relationship of management and leadership. Those issues can prove whethe management is largely concerned with leadership.

Seondly, with the developmen of strategy, strategic management are more and more important in the circumstance of management. To discuss Hannagan's statement, it is likely to analyse what strategic managemnt is and what roles leadership play in strategic management.

Moreover, Hannagan's statement says the reason is "because managers need to establish a sense of direction and to motivate people in that direction." Consider of this statement, it can be significant to see what responsibilities managers have. Thus, this paper will argue three issues that include management and leadership, strategic management and leadership and the responsibilities of managers.

\section{Management and Leadership:}

Schermerhorn (1989) states that management is a body of knowledge and field of academic inquiry based on scientific principles and serving as an important foundation for any manager. He describes that leadership is the manager, by use of power, to influence the behaviour of other persons in the work setting. This statement can be considered that management offer the job opportunities to the managers and leadership is about how the managers communicate and coordinate with others by use of their powers.

The latest arguments of management and leadership by Robbins and Coulter (2005) are that management is simply what managers do. But more explanations are that management is coordinating work activities in order to complete efficiently and effectively with and through people. They contrast managers and leaders, and conclude that all managers should ideally leaders but not all leaders have the capability or skills as same as effective managers, which means not all leaders should be managers. Meanwhile, they indicate that leadership is the processing of influencing a group toward the achievement of goals.

However, to make sure whether management is largely concerned with leadership, these issues are not sufficient to prove it. Therefore, the following texts show the relationships between management and leadership.

\section{The functions of management and leadership:}

As it is mentioned above, management is the process of getting activities completed efficiently with and through other people. And five basic management functions support the process of setting and achieving goals: planning, organizing, staffing, directing/leading, and controlling; that utilize human, financial, and material resources [3].

According to Australian natural and cultural heritage theme report, management is concered with making conscious choices about what happens and taking action to make those things happen. Management includes the widest possible range of actions and decisions, for example [4]:

- $\quad$ establishing the appropriate decision-making group and processes;

- $\quad$ assessing significance;

- $\quad$ deciding to open or not open a site to visitor;

- $\quad$ approving works and conservation;

- $\quad$ setting up decision-making structures to implement strategies;

- $\quad$ arranging access rights or means to achieve access

- $\quad$ deciding to take action

These functions imply that management is concerned with many aspects so that manager can maximize the output of the organization through the administrative implementation. 
According to Vroom Leader Participation Model, the functions of leadership are to decide, to consult individually, to consult group, to facilitate and to delegate. These functions are more about leading and controlling people and more specific than the functions of management.

\section{The difference between management and leadership:}

Thomas J. Peters say" Manament is about arranging and telling. Leadership is about nurturing and enhancing. [5]" Robbins and Coulter also say that it is impossible to the successful management without strong and committed leadership in the controlling function since leadership is an organizational behaviour topic. Leadership is likely to be ability of a manager to achieve the goals effectively and efficiently, as management need to plan, to organize, to direct, to staff and to control[1].

Compare with the functions of management and leadership, these issues also prove that leadership is just one of the many assets that a successful manager must possess. Leadership is definitely a very important component of management, but in some circumstances leadership is irrelevant. For example, selfmotivated groups may not require a single leader and may find leaders dominating. The fact that a leader is not always required proves that leadership is a facet of management. [6]

\section{Strategic Management and Leadership:}

Nowadays, David (2003) argues that, to achieve and maintain competitive advantage, strategic management is more and more important since it is a set of the managerial decisions and actions that determine the long-run performance of an organization. It is an important element of management and comes into all of the basic management functions[2]. Johnson, Scholes and Whittington (2005) describes that strategic management is not only the management of the process of strategic decision making, but also concerned with complexity because of ambiguous and non-routine situations with organization-wide rather than operation-specific implications. They state that strategic management includes understanding the strategic position of an organization, strategic choices for the future and turning strategy into action.

\section{Strategic management:}

\subsection{Understanding the strategic position of an organization:}

Strategic position is related to distinguish the impact on strategy of the external environment, an organization's strategic resources and competences, and the expectations and influence of stakeholders.

The organization exists in the complex world mixed by politics, economy, society, technology, environment and law. Its resources and competences depend on strengths and weaknesses, which is a view of internal influences and is usually a combination of resources and high levels of competence in particular activities for achieving competitive advantage. Indeed, strategic position is in a decision making stage of strategic management and it draws a view of the vital influences on strengths and weakness of internal environment, the capabilities and the expectations of stakeholders.

\subsection{Strategic choices for the future:}

Strategic choices involve understanding how the organization seeks to compete at the business level and which direction could be in the future. Based on the competitive advantage. At the highest level, in an organization, it is concerned with the scope of an organization's strategies that includes decisions about the production and the spread of market. Strategic choices for the future also develop in different directions. For instance, Dell is going to develop their current products and customers and extend product range and target market. Dell chose developing internal situation as strategic choice, but other companies might choose merging and strategic alliance with other organisations. This example shows strategic choices is a very important stage of strategic management. [7]

\subsection{Turning and strategy into the action:}

Strategy into the action includes that structuring an organization support successful performance, enabling success through the way in which the separate resource areas of an organisation support strategies and managing strategy involves change.

Structuring organization for success is referred to organizational structure, process and relationships. Enabling strategies are not only concerned with organization support strategies but also relate to build new strategy on organization resources and competences. In the organization, managing strategy often connect with the different types of roles for people play and change.

\section{The relationships between strategic management and leadership:}

\subsection{Team leadership is a significant element for understanding} the strategic position:

As it described above, strategic position needs to distinguish external environment of an organization. With the development of organization, Day, Hall, Gammage and Coles (1993) argue that leadership increasingly occurs within teamwork in a large number of organizations. And the role of team leaders in directing team members has become more and more important. The reason is explained by them because team leaders are liaison with external environment such as team leaders need to deal with the relationships among upper management, other organizatinal work teams, customers or suppliers. They also need to represent the team, clarify others' expectations of the team, gather information from the outside and share information with team members. Based on their arguments, at the stage of strategic postion, an effective team leadership absolutely play a significant role.

\subsection{Leadership play an important role in managing strategy:}

Boulding (1985) states that "the greatest need for leadership is in the dark... It is when the system is changing so rapidly ... the old prescriptions and old wisdoms can only lead to catastrophe, and leadership is necessary to call people to the very strangeness of the new world that is being born.[8]" This statement definitely displays leadership is very essential factor in the organizational change. Looking at the 
contents of strategic management, the relationship between strategic management and leadership can be found that leadership plays a significant role in the stage of strategic action. Especially internal organization change and the management of change is often directly linked to the role of a strategic leader. Within the definition of leadership, leadership is the process of influencing an organization for achieving a goal. In strategic management an effective leadership can make leaders understand how manage strategy and change.

Tom Peters and Waterman (1982) argue that 'transforming leadership' is the ability of leader to 'obtain extraordinary effort from ordinary human beings'. According to transformational leadership theory, leaders have ability to encourage followers transcending their own self-interests for the good of the organization and have extraordinary effect on the followers. These issues can be discovered in Jim Goodnight of SAS Institute and Andrea Jung of Avon. These companies focus on concerns and developmental needs of individual followers, change followers' awareness of issues by looking at the old problems into new ways and stimulate the followers putting extra effort to achieve organizational goals. [9]

\section{Conclusion:}

This paper argues Hannagan's statement from three issues and divides the statement into leadership and the responsibilities of managers. Management and leadership, strategic management and leadership are mainly related to the beginning of the statement that management is largely concerned with leadership.

However, Hannagan's statement is accurate but partial. Management and leadership argue that management do not only refer to leadership but also many aspects which include planning, organizing, staffing, directing/leading and controlling. In self-motivated groups, leadership is even irrelevant. The responsibilities of managers also express the wider view. Managers do not only need to establish a sense of direction and to motivate people but also need to organize activities and employees for achieving goals and objectives. With the variety of positions and duties, managers even play different roles. Some can be the creator of policy but some can be the implementer of policy. Managers also need to make human resource strategy, to select new employees and or terminate staff.

In such a brief study, it is hard to say Hannagan's statement really contain all the contexts of management and leadership. It only can say that his argument reflect the facet of management and leadership. However, with the developmene of acdemic study, it entirely need to think over whether his statement is reasonable and comprehensive.

\section{References:}

[1] D'annuzion-Green, A.Maxwell, G and Watson, S(2002,ed) Human Resource Management:International perspectives in Tourism and Hotel Management. In UK Thomson Learning.

[2] David F.R (2003) Strategy Management- Concepts \& Cases United States of America Pearson Education, Inc.

[3] Source: www.crfonline.org/orc/glossary/m.html

[4] Source:www.deh.gov.au/soe/2001/heritage/glossary.html

[5] Source: http://en.thinkexist.com/quotes/thomas_j._peters/

[6] http://www.see.ed.ac.uk/ gerard/MENG/ME96/Documents/Intro/leader.h tm

[7] Source: Johnson G, Scholes K and Whittington R (2005, $7^{\text {th }}$ ed) Exploring Corporate Strategy England Pearson Education Limited pp19

[8] Source: Georgiades N and Macdonell R (1998) Leadership For Competitive Advantage England John Wiley\& Sons Ltd pp75

[9] Source: Robbins, S.P and Coulter, M (2005, $8^{\text {th }}$ ed) Management Unite States of America Pearson Education, Inc. pp433 